inasmuch as in no part of the world is there such unrestricted conjugal choice. But how does beauty originate? Sometimes suddenly, the offspring being incomparably superior to the parents; more frequently by gradual improvement, though certainly very pronounced in a large proportion of cases. A Darwinian would say this was owing to fortuitous variations and natural selection. But these ' fortuitous' variations Darwin did not attempt to explain. To do this is the task of modern evolutionists. It must be a gradual process so far as details are concerned.

In a paper read at the recent meeting of the American Association, I traced the influence of monotony in the environment, among other causes, in determining race degeneracy in a small and isolated community in the Bahama Islands, and endeavored to place this upon a scientific foundation. In a somewhat elaborate paper just read before the Canada Medical Association, I have advanced a new theory as to nutrition; viz., that the nerve centres are constantly exercising an influence over the nutrition of all the tissues of the body through the nerves distributed to them. This view supplements and explains that maintained in the first paper. It seems to me that it throws an entirely new light on the whole subject of evolution, supplies, in fact, a missing link in the explanation, - at all events for all animals with a nervous system, - and accounts for the origin of variations as, so far as I know, no other theory does. It furnishes what the Lamarckians have lacked but never supplied. I cannot, of course, give in this letter the facts on which this law is founded, but may say that they are of a threefold character: clinical, pathological, and physiological.

The form, etc., of every organ depends upon its mode of growth, upon its nutrition. According to the above theory of a constant neuro-trophic influence, the nutrition is every moment dependent on the nervous system. Now as it is through this system the organism is brought into relation with its environment, so through it the environment is registering its effects every moment. One thing seems to be settled in regard to beauty: it cannot originate when the existence is a purely vegetative one, devoid of all excitement of a psychical kind. That beauty is most frequent among the classes of the community in easiest circumstances, with opportunities for varied excitement of mind (and consequently of body), can thus be understood. That the mental mood causes the face to vary very much in expression is patent to all, and is understood by the influence of the mind over the muscles through nerves by influences radiating from the nerve centres. My theory goes much further than this, however, and assumes a constant influence of the nervous system directing the nutrition of every cell and so the form of the entire organism. By such a view we are able to understand how the young being in utero can be moulded to beauty or the reverse, by the environment of the parent. It may be long before we are able to work out the details, but we must not be hopeless even as to that.

This then is a physiological explanation of evolution. Now, although on reflection it must appear that all final explanations of evolution must be physiological, it is remarkable that scarcely a single physiologist has undertaken the solution of any of its problems. I hope to be able in the near future to elaborate the subject from the physiological standpoint and along the lines indicated above. And it is because this explanation seems to bear so directly on vital questions like those treated by Mr. Finck that I write to Science on the present occasion.

It is evident that for the best results to mankind there must be the freest choice in conjugal mating. We think biology has now advanced far enough to say of certain persons that they cannot mate without danger of deterioration in the offspring, e.g., in the case of those with a pronounced consumptive or strumous ancestral history; and it says much for the character of those who, with this fear before them, have sacrificed the prospects of conjugal happiness for a time, for the good of the race, by remaining in celibacy. An accomplished, experienced, and wise physician, well educated in the principles of heredity, might often, if consulted, be justified in saying nay. That he could say that any particular union is the best possible, is going far beyond our present biological knowledge.

With the inferior animals we can predict results as to offspring with a certainty that is remarkable. But with man the environment is so much more complex, from his more involved social life, from his high cerebral development (psychical life), that it is impos- sible to estimate all the factors in the environment ; and, if we could; we do not yet know exactly how they act. But nature has not left man without a sure guide. By man's instincts (intuitions) light is supplied, in each instance, that science can as yet give only as general principles. The individual is a light unto himself, provided that he has lived an honest, pure life.

For myself, on this point, I hold the strongest views. My theory as to falling in love would be something to this effect: there are in normal minds the elements of an unformed ideal, which takes definite shape when the person answering to that ideal appears, provided there be no interfering causes. This ideal appertains rather to type of individual than to any special person; i.e., there is the potential capacity to love one of many individuals of the type, and the exact individual of this type chosen may be a fortuitous matter. Good results, if not absolutely the best, follow in such cases, no matter which one of the type-class is chosen. As Carlyle said, "No man can love but once, and some not then." The choice of those of opposite tendencies, etc., results in a large proportion of cases in the highest good alike to the individuals themselves, their offspring, and the race. Man and woman in the conjugal state should be the one complementary to the other. The education of the sexes should lead to as much differentiation as possible, in order that the total energy available for the race may be maximal. The education given by parents and the general education of the public should be such as to allow of the highest degree of free, intelligent conjugal choice. If this is accomplished the results as regards beauty will be equally good with those in other directions. I seem, Mr. Editor, to be just getting into the subject, but I fear I have already taken up too much of your space; the importance of such a question must be my excuse.

Physiological Laboratory, McGill College,

T. WESLEY MILLS. Montreal, Aug. 29.

\section{The Study of Geography.}

THE efforts of the Royal Geographical Society towards the improvement of geographic teaching in England, as recently described in Science by Mr. Keltie, deserve particular attention, both from the success already attained and from the need of going still further. The success is conspicuous, if measured only by the recognition and opportunity given to Mr. Mackinder as reader in geography at Oxford; and the advance already gained in the character of models, maps, and illustrations is admirable and enviable; but I cannot help feeling that the shortcomings of the scheme are also apparent. It seems to me that geography itself needs as much attention as the means of teaching and illustrating it: the principles to be taught and the facts to be illustrated need fuller discussion and better choice than they have yet received. But Mr. Keltie, in his recent article in Science, says : "Of what is known as physical geography - the topographical surroundings of humanity - there is not much to complain: its facts and principles are pretty well known, and fairly set forth in numerous text-books. It is when we come to apply these facts to humanity, and deal with their bearings on the development of man in communities, that we find so much to desire." I sympathize fully with the second sentence of this quotation, but not at all with the first. Certainly much is still to be done in recognizing and illustrating the bearing of geographic facts on the development of human communities, but quite as much, or more, is yet to be accomplished in the careful study of the facts themselves. $\mathrm{Mr}$. Mackinder, in his address to the Royal Geographical Society (Proceedings, March, 1887), includes these geographic facts under 'physiography,' and their relations to humanity under 'physical geography ;' but the illustrations that he presents are chiefly of the latter subject, and the tendency of the Society, judging by the character of its Journal of former years and its current Proceedings, is, with small exception, in the same direction. It should be noted, however, that Mr. Mackinder gives much more importance to geologic origin of geographic forms than has been usual. Now it may be true, though I think it is not, that enough is known of physiography to serve the wants of physical geography; but it is undoubtedly true that physiography as a science in itself is in a most immature condition, and is only in recent years obtaining: 
recognition. Physiography now is in the low position that natural history occupied in the first half of the century, when its textbooks gave brief descriptions and pretty little wood-cuts of a great variety of forms, dwelling on their slight differences more than on their great resemblances. In a score or more of years, physiography will be fortunate if it attain as high a position as is now held by biology, the successor of the old natural history, in which a few forms are first studied minutely, and the knowledge of detail thus gained is broadened by giving emphasis to the resemblances that relate these few types to all the rest of the animal and vegetable world. As far as the economic relations of plants and animals to human history are concerned, some might be content with such a statement as 'a horse is a horse;' but the study of zoölogy for itself, without regard to its relations to history, must regard a horse as a highly specialized form of a general type, and must discover how his specialization was accomplished.

Physiography must make the same advance. It might serve the needs of physical geography if physiography made no distinction between a new plain smoothed by constructive process and an old base-level plain smoothed by destructive process; but to physiography itself the omission of this vital distinction is absolutely fatal. Placing such apparently similar forms together would involve the same order of error as that of classing whales with fishes, or of grouping the unwrapped cephalopods of the mesozoic with the straight forms of the low paleozoic. Time must be recognized as an element in geographic description even to a greater degree than it has been by Prof. Archibald Geikie in his study of 'geograpic evolution;'. for topographic development is the key to a real understanding of the forms of the land about us. Physiography must, moreover, follow the example of biology in studying its simpler type-forms carefully before attempting to understand the complex associations of forms that make up a country or a continent.

Continental homologies have gone far enough already, if indeed not too far, in the present state of knowledge: attention should be directed instead to the minute morphology and systematic development of individual topographic forms. The difficulties of such work are great, especially in teaching ; for while it is admitted that 'seeing is believing,' and methods of instruction in chemistry, physics, and organic natural history are all remodelled with this principle in view, geography can at best secure but an imperfect application of the principle, and has to get along with maps, views, and models, instead of studying actual forms themselves. Maps are nearly always on too small a scale, and too poorly drawn to show what ought to be seen. Photographs are of course extremely useful, but they generally include too many varieties of form, and present too much detail, to serve best in elementary instruction; and they are as a rule taken with a geographic rather than a physiographic object. Illustrations in books of travel are too often of no scientific value : the traveller is generally an explorer instead of a geographer, and the artist too often stays at home. Most of Holzel's oleographs are admirably artistic, and all are highly valuable, and they probably come as near to being 'types' as any thing published. The illustrations in the reports of our Geological Survey are also most excellent in this respect. Models are too often merely copies of actual places that have been, for such a reason as complexity of structure or the like, chosen for this kind of illustration: the model of Monte Rosa mentioned by Mr. Keltie, excellent as it must be as the work of so artistic a geologist as Professor Heim, and so appreciative a topographer as Herr Imfeld, must have about the same relation to the needs of a class in physiography as a menagerie would have to the needs of a class in biology, or as Leverrier's computations about Neptune would have to a class in mathematics. Mr. Keltie recognizes, however, that, for teaching purposes, "it should be remembered that it is not extraordinary features that are desired, but typical aspects of the earth's surface," but he does not say where we shall find a scientific and sufficient investigation of the forms that are to be chosen as 'typical aspects.' There is no such investigation. The absence of any thorough and consistent physiographic terminology at once points out the immaturity of this study. Beginnings may be found here and there, but certainly not in 'numerous text-books.' The Sixth Annual Report of the Geological Survey, just issued, contains, for example, a number of illustrations that will be seized upon when the proper text-book appears. The choice little woodcuts on page 229, entitled 'Topographic Old Age,' and 'Topographic Youth,' are particularly good, but these terms will certainly be new to most readers.

Let me repeat, therefore, that while the principles of physiography are coming to be pretty well understood, the facts have yet to be set forth in their proper light, and the world must be explored over again to find them. Let any one who doubts this read over the ordinary books of travel and the older geological and geographical reports, and see what sort of a physiography he can make out of them. Before the methods of teaching physiography are perfected, before the proper illustrations are constructed, much discussion is needed as to the principles to be taught, and as to the forms that are to be chosen for types. The Geographical Society still has a large work before it in this direction.

W. M. Davis.

Cambridge, Mass., Aug. 28.

\section{The Blair Educational Bill.}

IN Science of Aug. I9 is a note on the Blair bill, by James Lawrey of Iowa. Mr. Lawrey declares that " any State that would accept national aid has not the spirit necessary to a sound government." Such a statement comes with very poor grace from one who resides in a State in which the schools are most richly endowed by the general government. Whence came the great educational funds of the western States, save from the munificent bounty of the general government? Has the spirit of the people of the State of Iowa, or of any western State, been, in any way, injured by the vast donations of land by the general government to these States? I understand that the great north-west was ceded to the nation for the benefit of all the people, by certain States having a good claim to the same. The later acquisitions by purchase and by conquest were all intended certainly for all the people. But in what way are the people of Pennsylvania or of Virginia benefitted by the school funds of Iowa or Nebraska, derived from the sale of lands belonging to all the people? These great land-grants are but little understood by the people of the East. A few years ago, when in Nebraska, I was told that the school lands of that State, if laid out in a belt two miles wide, would extend from the Atlantic to the Pacific Ocean.

I believe in the aims of the Blair Bill most fully, but I think it should be modified, in several particulars. I. The money should be given to each State for the benefit of all school children in the same, but with no other restrictions. 2. The western States should receive no benefit from the grant until the old States have been granted sums to counterbalance the grants to the western States.

It is certainly a grave mistake on the part of our rulers to collect vast sums of money, more than are needed to conduct the government in an economical manner, but when once it is collected it should be returned in the most direct manner possible.

The South needs the aid. With ungallant restrictions removed, she will accept and make good use of it, I feel as sure as I do that it would do good in my own State. Geo. G. Groff.

Bucknell University, Lewisburg, Penn.

\section{Wind Pressure and Velocity.}

REFERRING to Mr. H. Allen Hazen's letter in your issue of the $2 \mathrm{~d}$ inst., I beg to call attention to the fact that the temperature of the wind enters as an important factor in the determination of the pressure due to a given velocity. In 1876 (Engineering and Mining Journal) I first pointed out that a variation in temperature from $O^{\circ} \mathrm{F}$. to $100^{\circ} \mathrm{F}$. produces a difference in the amount of pressure, for a given velocity of wind, of over one-fifth the total amount. I have since discussed the subject more fully in a little treatise on 'The Windmill as a Prime Mover' (New York, John Wiley \& Sons, I885), giving detailed formulæ and complete tables, showing the relation between the pressure and velocity of "wind.

Further accurate experimental determinations are certainly necessary, but all data entering the problem (among them, the temperature of the impinging air) should be carefully noted, and given due weight in any generalization drawn from the experiments.

New York, Sept. 5. 